\title{
GROUP-TACIT KNOWLEDGE AND ORGANISATIONAL EFFECTIVENESS: ANALYSIS OF EFFECTS USING A MIXED METHOD APPROACH
}

\author{
Ayodotun Stephen IBIDUNNI ${ }^{1}$, Maxwell Ayodele OLOKUNDUN ${ }^{2}$, \\ Deborah Bolanle MOTILEWA ${ }^{3}$, Tolulope Morenike ATOLAGBE ${ }^{4}$, \\ Omotayo Adewale OSIBANJO 5
}

\author{
${ }^{1}$ Department of Business Management, Covenant University, PMB 1023, Ota, Ogun State, Nigeria \\ 2, 3, 4, 5 Department of Business Management, Covenant University, Ota, Ogun State, Nigeria \\ Emails: ${ }^{1}$ ayodotun.ibidunni@covenantuniversity.edu.ng (corresponding author); \\ ${ }^{2}$ maxwell.olokundun@covenantuniversity.edu.ng; ${ }^{3}$ bolanle.motilewa@covenantuniversity.edu.ng; \\ ${ }^{4}$ tolulope.atolagbe@covenantuniversity.edu.ng; ${ }^{5}$ ade.osibanjo@covenantuniversity.edu.ng
}

Received 24 November 2017; accepted 18 February 2018

\begin{abstract}
Considering that most part of organisational operations depend on group effectiveness, yet there is scarcely any empirical study on the interactions between group-tacit knowledge and organisational effectiveness. In order to overcome this gap, this study involves a survey of 230 managers and other administrative \& technical employees of the four major firm in the Global System for Mobile Communication (GSM) sub-market of Nigeria’s telecommunications industry. Data was gathered using a mixed method research approach. Correlation, Regression, Analysis of Variance (ANOVA) statistics and thematic analysis was carried out as means of testing the hypothesis for this research study. The findings showed that firms need to focus keenly on ideas of employees that are shared during conferences, team leaders' mentoring role, collective reasoning over task and constantly hold strategic meetings that probe into developments arising in each functional unit of the organisation. These factors are shown to have a strong influence on organisational effectiveness.
\end{abstract}

Keywords: group-tacit knowledge, organisational knowledge, organisational effectiveness, telecommunication, knowledge management, mixed method research.

JEL Classification: M1.

\section{Introduction}

Group-tacit knowledge involves the coming together of individual members of the organisation to act in a collective and coordinated manner and to solve complex tasks, as a way of achieving organisational effectiveness (Erden et al. 2012, Naser and Sajad 2017). Although knowledge is created in the minds of individuals, the development and progressive increase in individual knowledge occurs within a social context of group interactions (Nasimi et al. 2013, Nonaka et al. 2000). Owing to the highly personalized nature of tacit knowledge, Agbim, Owutuamor and Oriarewo (2013) opined that tacit knowledge among groups is gained as organisational members gain experience on their jobs, and being under the tutelage of experts. This implies that group-tacit knowledge reflects in the experiences shared on the job and the expertise that arises by reason of learning subtle skills and know-hows that are not common to most members of a profession and, indeed, the organisation.

According to Li, Chang, Chen and Jiang (2010) grouptacit knowledge has the advantage of enhancing the effectiveness of organisational members' ability to forecast events relating to their operations. This is because, leveraging on experience and leveraging on collective knowledge sharing they are able to predict future events and thus, ensure effective strategic planning. This view therefore, emphasizes the fact that organisational effectiveness basically resides 
in the ability of organisational members to think corporately for the benefit of the organisation. Part of the challenge for managers therefore is to manage the process that stimulates expert in the organisational members to share their knowledge for the purpose of achieving higher performance. According to Agag and El-Masry (2016) individuals' willingness to share knowledge in organisations is influenced by factors imbedded in motivators, for example, personal benefits; barriers, such as, organisational culture; and knowledge enablers, namely: inter-personal trust and information technology. Zhang, He and Zhou (2013) showed that industries and projects that operate in a dynamic environment, yet demanding effectiveness and efficiency in work processes can take advantage of integrated project development (IPD). The IPD concept enhances team, and by extension organisational, effectiveness through the collaborative expertise of teams, usually known as integrated project team (IPT).

In organisations, group tacit knowledge resides in the collective understanding which organisational members have about their work and organisational processes. It would reflect in their beliefs, values and cultural patterns of relationships, work flow systems and knowledge sharing. Fei, S. Chen and S. L. Chen (2009) and Ibidunni, Ogunnaike and Abiodun (2017) suggest that group-tacit knowledge would reflect in the firm's culture and relationship with customers, suppliers and other external parties. It can also be linked to what Hinton (2003) called communities of practice. According to Obeidat, Tarhini, Masa'deh, and Aqqad (2017), group-tacit knowledge has the ability to propel creative patterns to achieving organisational effectiveness. Organisational effectiveness implies the capability of the firm to attain its broad goals, cutting across internal and external stakeholders' requirements (Zoogah et al. 2015). Pivar, Malbašić and Horvat (2012) also suggested that effective tacit knowledge sharing among organisational members will result in effective organisational systems and work processes.

Empirically, testing the relationship between organisational knowledge and effectiveness is not uncommon in the literature. Studies, such as Gold, Malhotra and Segars (2001); Zheng, Yang and McLean (2010) and Jasimuddina and Naqshbandib (2018) explained the relationship between organisational knowledge and effectiveness from a perspective of knowledge infrastructure. In their opinion, organisational knowledge stored in the organisation's ITbase can be easily retrieved at any point-in-time and when required for resolving organisational challenges and enhance effectiveness. However, this approach has not demonstrated how tacit knowledge from a group of people can enhance organisational work process and achieve effectiveness. Thus the measurement of organisational effectiveness in existing literature have not adequately reflected the actual usage of group/collective knowledge, especially group-tacit knowledge. This research proposes, that a methodology of viewing organisational knowledge based on the actual usage of group-tacit knowledge to achieve organisational effectiveness should be adopted. Consequently, examining organisational effectiveness based on groups' engagement of actual use of their knowledge, especially their group-tacit knowledge, present a more real explanation to organisational outcomes.

\section{Literature review}

\subsection{Group-tacit knowledge in organisations}

Group-tacit knowledge is collectively shared firm's image, culture and patterns of relationships with the external environment (Fei et al. 2009). Erden, Von Krogh and Kim (2012) opined that a firm's group tacit knowledge could reflect in the capacity of its members to execute agreed upon tasks with their collective mind in the case where explicit means are not available. This view presents grouptacit knowledge in organisations as a substitute for explicit knowledge such that where one is present the other might not be of necessity. However, there are organisational tasks which by necessity require the expertise of tacit knowledge of collective mental efforts from more than one individual in the organisation (Swart and Pye 2003, Jad et al. 2017). Much about Orlikowski's (2002) empirical study on knowing in practice can be captured by the group tacit dimension of organisational knowledge. Thus, firm's shared identity, face-to-face interactions and alignment of efforts through the use of common models would be essential means of transmitting tacit knowledge among members of an organisation.

According to Urbancová (2013) and Giedraitis, Stašys and Skirpstaite (2017) organisations can benefit from the knowledge sharing process of their knowledge workers and team members to enhance innovation and thus achieve high performing firms. Vital to this process is the ability of these knowledge workers to exploit their collective experiences as a means of creating value-adding products/services for the firm and its customers. Often, we speak of community of practice which involve the flow of knowledge among experts in the same or similar profession. Group-tacit knowledge utilisation can be discussed in two forms: a state where organisations attempt to extract tacit knowledge of individuals or groups and transform it into explicit forms that can be reused at any point of the organisation's existence and need. The other means include the use of group tacit knowledge in its tacit form to create value for the organisation. Swart and Pye (2003) acknowledge the possibility of the latter case.

Goffin and Koners (2011) opined that the complex process of developing new products and innovative projects within organisations very often require this form of group-tacit knowledge interactions which are highly personal and informal in nature. In their view, organisation's 
management must facilitate the sharing of tacit knowledge among groups by ensuring that there are mechanisms put in place to motivate employees, secure their commitment and reward them for sharing their knowledge. Also, organisational structures, should be one that support tacit knowledge transfer in the easiest possible way.

According to Mahroeian and Forozia (2012), organisational management must be mindful of dealing with length of time, value, perception and language, and distance, as critical factors when considering tacit knowledge sharing among groups. In their view, these factors could pose as barriers to the knowledge sharing process if not adequately addressed. Hostle and Fields (2010) also share that trust issues could hinder tacit knowledge utilization among groups. They revealed that two major types of trust must be concentrated on, they are: affect based trust and cognition based trust. It is therefore important that organisation's management ensure that employees create relationships based on mutual interactions (affect based trust) and that they place recognition on one another's expertise (cognition based trust) during the knowledge sharing process (Olaisen and Revang 2017).

Pivar, Malbašic and Horvat (2012) examined the role of personality and attitude of employees on group tacit knowledge use in organisations. They therefore, emphasized the importance of mentoring and coaching as means of group tacit knowledge sharing. However, Kothari, Rudman, Dobbins, Rouse, Sibbald and Edwards (2012) posited that mentoring will be more effective within groups with a composition of people that act, think and agree together. In other words, group composition must consist of like minds. They also shared the importance of story-telling by mentors, coaches and group members as strategies of tacit knowledge sharing among groups.

\subsection{Organisational knowledge and effectiveness}

Organisational effectiveness is defined by the firm's ability to realise its goals (Daft 1995). Thus, it reflects the extent to which organisational members collectively engage the firm's tangible and intangible resources, including their knowledge about firm's processes and environment, to produce significant results (Alsharoa et al. 2017). Linking organisational knowledge and effectiveness has to do with how well knowledge is managed and organized to achieve organisational goals. Empirically testing the relationship between organisational knowledge and effectiveness is not uncommon in literature.

Yang (2015) observed the importance of knowledge management in the internal marketing field. The study aimed at investigating the effect of internal marketing on knowledge sharing and organisational effectiveness. Findings revealed that knowledge acquired from conversations help the company to provide customers with the right offerings, thus also resulting in enhanced organisational effectiveness and marketing competitiveness. In another study, Hsin-Kuang, Chun-Hsiung and Dorigotov (2012) suggested that knowledge management tools and initiatives positively contribute to organisational effectiveness. Also, managers who create new knowledge and innovatively apply them in the market tend to be more effective in influencing organisational effectiveness (Ogbari et al. 2018). Table 1 shows a series of measures which have been adopted for the measurement of organisational effectiveness.

Table 1. Measuring organisational effectiveness

\begin{tabular}{|c|c|c|}
\hline Author(s) & Measures of Organisational Effectiveness & Context of Study \\
\hline Matthews (2011) & Multidimensional Approach based on performance models & \\
\hline $\begin{array}{l}\text { Zheng, Yang and } \\
\text { McLean (2010) }\end{array}$ & $\begin{array}{l}\text { Organisational members' perceptions of the degree of the overall success, } \\
\text { market share, profitability, growth rate, and innovativeness of the orga- } \\
\text { nisation in comparison with key competitors }\end{array}$ & $\begin{array}{l}\text { HR professionals of two organi- } \\
\text { sations }\end{array}$ \\
\hline $\begin{array}{l}\text { Kroeger and Weber } \\
(2015)\end{array}$ & $\begin{array}{l}\text { Multidimensional Approach that constitutes three types of models: goal } \\
\text { models, system resource models, and functional models }\end{array}$ & $\begin{array}{l}\text { Not-for-profit and social enter- } \\
\text { prises }\end{array}$ \\
\hline $\begin{array}{l}\text { Zoogah, Peng and } \\
\text { Woldu (2015) }\end{array}$ & $\begin{array}{l}\text { Multidimensional Approach based on internal and external factors that } \\
\text { reflect long and short term periods }\end{array}$ & African context \\
\hline $\begin{array}{l}\text { Gold, Malhotra and } \\
\text { Segars (2001) }\end{array}$ & $\begin{array}{l}\text { A multidimensional Approach that draws on innovation, responsiveness } \\
\text { to market demands, proactive dispositions, continuous improvement on } \\
\text { internal processes, and so on }\end{array}$ & $\begin{array}{l}\text { Senior Executives of Knowledge } \\
\text { Management activities }\end{array}$ \\
\hline $\begin{array}{l}\text { Giti and Suhaida } \\
(2012)\end{array}$ & $\begin{array}{l}\text { Multidimensional approach that reflects both organisational and custo- } \\
\text { mer perceptions }\end{array}$ & $\begin{array}{l}\text { Dominant coalition members } \\
\text { in six institutions of Higher } \\
\text { education }\end{array}$ \\
\hline Cunningham (1977) & $\begin{array}{l}\text { Multidimensional approaches based on rational goal, system resource, } \\
\text { managerial process, organisational development, bargaining, structural } \\
\text { functional and functional }\end{array}$ & \\
\hline
\end{tabular}


Identifying which criteria is most appropriate for evaluating organisational effectiveness has been a major issue of contention in literature. However, most authors argue that a multidimensional approach is most appropriate since it captures a wider scope of organisational elements and presents a more accurate view of organisational effectiveness (Matthews 2011, Giti and Suhaida 2012, Selden and Sowa 2015).

Organisational effectiveness has also been perceived by the extent to which organisations are able to fulfil their Corporate Social Responsibility (CSR) objectives and significantly contribute to economic sustainability (Osabuohien and Efobi 2012, Ojeka et al. 2016, Dobrovolskienè et al. 2017). According to Jankalová and Jankal (2017) organisational effectiveness will depend on the extent to which management is able to mobilize resources and direct strategic initiatives of the organisation to meet all CSR dimensions, such as environmental, social, economic, stakeholder and volunteers. Moreover, Stjepanović, Tomić and Škare (2017) have considered green GDP as a viable means of organisational contribution towards economic growth. Green GDP refers to the efforts that organisations invest into ensuring sustainability of social and environmental capital such as their contributions in the aspects of human capital development and natural capital (Zavadskas et al. 2016, Oganisjana et al. 2017).

\section{Methodology}

This research study adopted the mixed method research design. The mixed method approach was adopted through the incorporation of both the quantitative and qualitative research designs and it is advantageous in its ability to infuse, in a single research process, scientific experimentation of perceived truth/reality with human opinions drawn from practical experiences in the work place (Johnson and Onwuegbuzie 2004, Plano Clark 2010). Previous related studies, such as, Molina-Azorin (2012) and Nemani (2009), have showcased the importance of using mixed method research design. The research study is descriptive in nature. The use of descriptive research design is validated by the fact that populations for the study is already established, theories are not newly explored or determined and the research study simply attempts to describe the relationships among the variables included in the research (Kovacic et al. 2014).

Survey method was adopted for the study because it gave the researcher the opportunity for gathering samples from a given population in order to examine the description, incidence and interaction of relevant variable pertaining to the research objectives. The choice of survey research method is also premised on its value and feasibility in addressing the research problem raised in the study. In addition, insights relating to the study can be easily gained from the subset of the population using the survey method (Taylor et al. 2014). In other words, given the population for this research study, the survey method enhanced accessibility to a subset of the population using a sample. More specifically, semistructured interviews and structured questionnaires were used to collect data from the sampled respondents.

\subsection{Measures}

This research benefitted from the ideas of existing research studies. Questions about group-tacit, knowledge was developed based on Chilton and Bloodgood (2007); Fei, S. Chen and S. L. Chen (2009) and Huang (2014). Items on organisational effectiveness as designed by Gold et al. (2001) were used. This perspective to measuring organisational effectiveness was considered appropriate for this research because the authenticity of it has been proven and adopted by several other research works, such as Rehman, Asghar and Ahmad (2015) and Shiaw-Tong, May-Chiun, and Yin-Chai (2016). The instrument contains items that measure organisational effectiveness based on the attainment of organisations' objectives. Such objective has been identified to cut across stakeholders both within and outside the firm and to include processes and activities that revolve around firms' integral operations.

\subsection{Sampling}

Managerial, technical and administrative employees of firms in the Nigeria telecommunications industry form the population for this study. The telecommunication industry is pivotal to this research because in the global business economy, this industry is recognised to be highly technologically driven (Oghojafor et al. 2014). Yet, in developing countries, such as Nigeria, technological sophistication is still very low, as such there are many shortfalls associated with the operations of the telecommunication industry (Alabar et al. 2014, CPC 2010).

Specifically four organisations in the GSM sub-market of the industry were included in this study. The GSM sub-sector is an essential subset of the Nigeria telecommunication industry because it has the highest number of subscribers (98.07 per cent), thus serving as the major driver of growth in Nigeria's telecommunication industry. A total sample size of five hundred and four (504) managerial and other technical and administrative employees was determined for this research work. A set of structured questionnaire were used in gathering responses for this research study.

The semi-structured interview instrument consisted of simple and short questions presented in open-ended format for management cadre employees and supervisors of the GSM telecommunication firms in order to let them extensively share their personal opinion on the relationship between organisational knowledge, orientation and firm performance. 


\subsection{Reliability and validity of the scale items}

The reliability of the research items was ensured using the internal consistency method while the validity of scale items was carried out using construct validity. The Coefficient Alpha ( $\alpha$ ) or Cronbach Alpha is the most popularly used measure of internal consistency (Pallant 2005). The values of $\alpha$ range from $0-1$. The closer the value of $\alpha$ to 1 , the more accepted the reliability of the data. The Cronbach Alpha internal consistency of the items of the questionnaire was analysed using the reliability procedure in SPSS and is presented in Table 2 below.

Table 2. Reliability of constructs and scale items

\begin{tabular}{|c|l|c|c|}
\hline S/No & \multicolumn{1}{|c|}{ Construct } & No. of Items & Cronbach's Alpha \\
\hline 1 & $\begin{array}{l}\text { Group-tacit } \\
\text { knowledge }\end{array}$ & 5 & 0.738 \\
\hline 2 & $\begin{array}{l}\text { Organisational } \\
\text { effectiveness }\end{array}$ & 4 & 0.873 \\
\hline
\end{tabular}

From the table above, Pallant's (2005) bench mark of 0.7 scale reliability is fulfilled by the constructs. Therefore, the scale items were found to be reliable for the constructs of this research study. The combine reliability of all items in the research instrument gave a reliability statistics of 0.811 , which also surpasses the benchmark.

Construct validity, on the other hand, has been used widely in literature as a means of ensuring that items in the research instrument are actually measuring the constructs they claim to be measuring (Brown 2000). Whereas some literature identify construct validity by using factor analysis to observe clustering of items, another way of determining construct validity is to explore the degree of correlation among items of a construct (Weiner 2007). Pae (2012) examined the use of correlation based construct validity on the Pearson Test of English academics. Therefore, this research study determined construct validity of the research items using the extent of convergence and divergent validity among the items in each construct of the research study as depicted in Table 3.

Table 3. Inter-item correlations of group-tacit knowledge and organisational effectiveness

\begin{tabular}{|c|c|c|c|c|c|c|c|c|c|c|c|}
\hline & Mean & $\begin{array}{l}\text { Std. } \\
\text { Dev. }\end{array}$ & 1 & 2 & 3 & 4 & 5 & 6 & 7 & 8 & 9 \\
\hline \multicolumn{12}{|c|}{ Group-tacit Knowledge } \\
\hline $\begin{array}{l}\text { The way I carry out my job is largely } \\
\text { guided by the organizational culture } \\
\text { of my firm (1) }\end{array}$ & 4.4444 & .67226 & 1 & & & & & & & & \\
\hline $\begin{array}{l}\text { Staff in this firm are encouraged to } \\
\text { share experiences among one anot- } \\
\text { her (2) }\end{array}$ & 4.3034 & .74475 & $.516^{* *}$ & 1 & & & & & & & \\
\hline $\begin{array}{l}\text { Most of the success I enjoy on my job } \\
\text { is a result of the shared experiences } \\
\text { gained from my colleagues ( } 3 \text { ) }\end{array}$ & 4.0778 & .76772 & $.307^{* *}$ & $.443^{\star *}$ & 1 & & & & & & \\
\hline $\begin{array}{l}\text { Staff of this firm often share stories } \\
\text { about past successes and failures of } \\
\text { their work (4) }\end{array}$ & 4.1628 & .71719 & $.280^{* *}$ & $.135^{*}$ & $.313^{* *}$ & 1 & & & & & \\
\hline $\begin{array}{l}\text { My colleagues are always willing to } \\
\text { explain difficult work processes to me } \\
\text { when I need them (5) }\end{array}$ & 4.2184 & .72216 & $.305^{* *}$ & $.386^{* *}$ & $.288^{* *}$ & $.442^{* *}$ & 1 & & & & \\
\hline \multicolumn{12}{|c|}{ Organisational Effectiveness } \\
\hline $\begin{array}{l}\text { Top management of my firm is quick } \\
\text { to adapt to unanticipated changes ( } 6 \text { ) }\end{array}$ & 3.6265 & .97168 & $.271^{\star *}$ & $.312^{* *}$ & $.302^{* *}$ & $.340^{* *}$ & $.372^{* *}$ & 1 & & & \\
\hline $\begin{array}{l}\text { My firm is very responsive to new } \\
\text { market demands ( } 7 \text { ) }\end{array}$ & 4.2262 & .81183 & $.345^{* *}$ & $.369^{* *}$ & $.193^{* *}$ & $.221^{\star *}$ & $.300^{* *}$ & $.427^{* *}$ & 1 & & \\
\hline $\begin{array}{l}\text { All units of this firm work in a coor- } \\
\text { dinated pattern to achieve the same } \\
\text { goal (8) }\end{array}$ & 4.1149 & .78393 & $.315^{* *}$ & $.391^{\star *}$ & $.259^{* *}$ & $.235^{\star *}$ & $.358^{* *}$ & $.484^{* *}$ & $.554^{\star *}$ & 1 & \\
\hline $\begin{array}{l}\text { Top Management are quick to adapt } \\
\text { the firm's goals/objectives to changes } \\
\text { in our market/industry (9) }\end{array}$ & 4.1395 & .81404 & $.324^{* *}$ & $.336^{* *}$ & $.276^{* *}$ & $.256^{\star *}$ & $.232^{* *}$ & $.512^{* *}$ & $.550^{* *}$ & $.491^{* *}$ & 1 \\
\hline
\end{tabular}

*. Correlation is significant at the 0.05 level (2-tailed).

**. Correlation is significant at the 0.01 level (2-tailed). 


\section{Results and discussion}

A total of two hundred and thirty (230) copies of questionnaire was retrieved from the organisational employees. The firms' employee base is largely dominated by female staff (31 respondents, or 68.9 percent) than their male counterpart (14 respondents, or 31.1 percent) out of which a total of 16 respondents (35.6 percent) are single while 27 respondents (60 percent) are married.

Most of the staff working with the firm have working experience ranging from six to ten years (33 respondents or 73.3 percent). A minute number of 11 respondents ( 24.4 percent) have spent five years and below working with the firm, while only 1 respondent (2.2 percent) has spent between eleven to fifteen years with the firm. This may imply that the firm has a weak employee retention strategy, and hence the organisational knowledge, especially tacit knowledge might not be sustainable over time since the carriers of such knowledge are not retained in the firm. Alternatively, the firm would be able to sustain its knowledge and establish a strong and competitive culture if it has mechanisms that capture knowledge of employees.

\subsection{Quantitative results}

The hypothesis that was tested for in this study states that: Group-tacit Knowledge does not have a significant influence on organisational effectiveness. This hypothesis was subject to the following set of analysis:

- Correlation analysis: to identify the extent to which employees in the organisations consider group-tacit knowledge a significant practice for achieving organisational effectiveness.
- Regression analysis: to statistically examine the explanatory power of group-tacit knowledge on organisational effectiveness.

- ANOVA analysis: to examine if there were any statistical differences in the perceptions of the four firms as to the importance of group-tacit knowledge in achieving organisational effectiveness.

The statistical result in Table 4 indicate that a moderate positive relationship exist between group-tacit knowledge and organisational effectiveness for Firm $1(\mathrm{r}=.47)$, Firm $2(\mathrm{r}=.52)$, and Firm $3(\mathrm{r}=.58)$. The result however showed a strong positive relationship between the two variables in Firm 4 , such that $r=.62$. The implication of the statistics is that group-tacit knowledge practice in the four firms increases organisational effectiveness. Therefore, there are indications that the organisations lay emphasis on collective reasoning in executing objectives.

The above Table 5 summarizes the result of regression analysis carried out to determine the impact of group-tacit knowledge on organisational effectiveness. The regression result indicate that group-tacit knowledge significantly influences organisational effectiveness of the telecommunication firms $\left(\mathrm{r}^{2}=28\right.$ percent, $\left.\mathrm{p} \leq 0.001\right)$. Thus, the explanatory power of group-tacit knowledge on organisational effectiveness is established as significant. The implication of the result is that the firms have a strong emphasis on group-tacit knowledge as a major determinant for achieving organisational effectiveness. This may also suggest that the firm has a strong culture of using team structures and knowledge sharing among employees in the firm to enhance their competitive positions in the telecommunication industry. Moreover, the model demonstrates a significantly

Table 4. Correlation coefficient of gtk and organisational effectiveness

\begin{tabular}{|c|c|c|l|}
\hline Firm Category & Pearson Correlation $(\mathrm{r})$ & Level of Significance & \multicolumn{1}{|c|}{ Remark } \\
\hline Firm 1 & $.469^{* *}$ & $\mathrm{p}<0.001$ & Significant and moderate positive relationship \\
\hline Firm 2 & $.522^{\star *}$ & $\mathrm{p}<0.001$ & Significant and moderate positive relationship \\
\hline Firm 3 & $.583^{* *}$ & $\mathrm{p}<0.001$ & Significant and moderate positive relationship \\
\hline Firm 4 & $.623^{* *}$ & $\mathrm{p}<0.001$ & Significant and strong positive relationship \\
\hline
\end{tabular}

${ }^{* *}$ Correlation is significant at the 0.01 level (2-tailed)

Table 5. Effect of GTK on organisational effectiveness

\begin{tabular}{|c|c|c|c|c|c|c|}
\hline \multirow{2}{*}{\multicolumn{2}{|c|}{ Model }} & \multicolumn{2}{|c|}{ Unstandardized Coefficients } & \multirow{3}{*}{$\begin{array}{c}\begin{array}{c}\text { Standardized } \\
\text { Coefficients }\end{array} \\
\text { Beta }\end{array}$} & \multirow{3}{*}{$\begin{array}{c}\mathrm{t} \\
4.227 \\
\end{array}$} & \multirow{3}{*}{$\begin{array}{l}\text { Sig. } \\
.000 \\
\end{array}$} \\
\hline & & \multirow{2}{*}{$\frac{\mathrm{B}}{1.285}$} & \multirow{2}{*}{$\begin{array}{c}\text { Std. Error } \\
.304 \\
\end{array}$} & & & \\
\hline \multirow{2}{*}{1} & (Constant) & & & & & \\
\hline & GTK & .657 & .071 & .530 & 9.259 & .000 \\
\hline 2 & $\mathbf{R}$ & \multicolumn{5}{|c|}{0.530} \\
\hline 3 & $\mathbf{R}^{2}$ & \multicolumn{5}{|c|}{0.280} \\
\hline 4 & $\mathbf{F}$ & \multicolumn{5}{|c|}{$\mathrm{F}(1,220)=85.729, \mathrm{p}<0.001$} \\
\hline
\end{tabular}


high F-value to validate its appropriateness in testing the predictive ability of the independent over the dependent variable, $\mathrm{F}(1,220)=85.729, \mathrm{p}<0.001$.

\section{ANOVA Test of difference in perception about organ- isational effectiveness in the telecommunication firms \\ Haven ascertained the relationships between group-tacit knowledge and organisational effectiveness from the per- spective that gathered opinion of the employees in the four firms, it was considered necessary not to assume that there are no differences between the firms' perspectives concern- ing organisational effectiveness. Therefore, in determining whether differences exist between groups about organisa- tional effectiveness, ANOVA was used.}

Table 6. One-way between-group ANOVA with post-hoc tests

\begin{tabular}{|c|c|c|c|}
\hline & $\mathbf{N}$ & Mean & Std. Dev. \\
\hline Firm 1 & 85 & 4.0412 & .64647 \\
\hline Firm 2 & 49 & 4.0510 & .71622 \\
\hline Firm 3 & 35 & 4.1714 & .57128 \\
\hline Firm 4 & 51 & 4.1078 & .56182 \\
\hline Total & 220 & 4.0795 & .63068 \\
\hline Levene Statistic & \multicolumn{3}{|c|}{$.606(\mathrm{p}=0.612, \geq 0.05)$} \\
\hline \multicolumn{4}{|l|}{ Sum of Squares } \\
\hline Between Groups & \multicolumn{3}{|c|}{$.501($ Mean Square $=.167)$} \\
\hline Within Groups & \multicolumn{3}{|c|}{$86.607($ Mean Square $=.401)$} \\
\hline F & \multicolumn{3}{|c|}{$.417($ Sig. $=.741)$} \\
\hline Df & \multicolumn{3}{|c|}{3,216} \\
\hline
\end{tabular}

Table 6 above show statistical results of the test of differences in the perception of employees of the four firms included in this research study about organisational effectiveness. From Table 6 all the mean values from the four firms indicate that they all tend towards a strong inclination to organisational effectiveness. The standard deviation values of less than 1 also suggest that respondents' views cluster around the fact that the firms' organisational effectiveness objective is being pursued and achieved. These are indicated by the statistics; Firm 1 (mean $=4.04$, std. dev. $=0.65$ ); Firm $2($ mean $=4.05$, std. dev. $=0.72)$; Firm $3($ mean $=4.17$, std. dev. $=0.57)$; and Firm $4($ mean $=4.12$, std. dev. $=0.56)$.

The test for homogeneity of variances shows that the homogeneity value is above 0.05 (sig. value $=0.612$ ). This therefore implies that the variance is score for all the four groups is the same, thus the assumption of homogeneity in variance was not violated. The ANOVA results show that there is no significant difference among the views of the employees in the four firms about organisational effectiveness (sig. value $=0.741)$.

\subsection{Qualitative results}

Theme: Utilizing Group-tacit knowledge to achieve organisational effectiveness.

\section{Firm 1:}

Respondents discussed a number of interesting views that revealed that they are aware of the existence of grouptacit knowledge practices in the firm and that knowledge sharing is the firm's major strategy for replicating expert knowledge among employees of the firm.

According to their views, regular trainings such as seminars, workshops, classroom discussions and what they tagged "online knowledge quest" are important strategies to the firm, and used in forming teams for the purpose of sharing knowledge and experiences that are necessary to stimulate employees towards achieving organisational objectives. The firm uses teaming both as a means of constantly sensitizing employees of the organisation's goals while at the same time making them aware of the required knowledge that could help them perform their role effectively.

An employee who has spent only less than five years in the firm opined that

- "Team work is an important culture for the firm" (Respondent 4)

- "The manager/supervisor who is the team leader assigns responsibilities and follow up with it to ensure that the work is done" (Respondent 7)

- "We report daily about the job to the manager/supervisor" (Respondent 6)

Another more experienced respondents with about fifteen years of experience on the job commented that

"Through our collective knowledge we are able to design/ redesign marketing strategies and achieve productivity from our markets" (Respondent 10).

The firm also has a culture that ensures teams are formed based on ability to reason alike on a project taking into consideration their major area of individual passion. Hence, their collective-tacit knowledge is channelled to enhance the organisation's performance.

"Teams within this organisation are formed based on the abilities, resourcefulness of the team members" (Respondent 1).

Essentially, this depicts that the firm's goals of utilizing knowledge to enhance performance does not only end at knowledge sharing but continues with effective monitoring and evaluation of actions emanating from using such knowledge in daily work.

\section{Firm 2:}

Respondents' views highlighted the importance of group-tacit dimensions of organisational knowledge to organisational performance.

Group-tacit knowledge is shared through daily briefings about experiences and encounters during the day's work, regular seminars, training and workshops. The firm has a culture of team formation that enhances mentorship among employees. In addition, the comment made by one respondent highlights that the firm encourages employees to use 
their knowledge and experience to achieve workable solutions to organisational problems and enhance performance.

"There is a board meeting held at regular intervals or on ad hoc basis in case of emergencies to discuss developments in various units, as well as welcoming practicable suggestions that will help to tackle prevailing issues" (Respondent 3 ).

"My firm adopts daily briefing in order for individuals to discuss about various issues experienced during the working period" (Respondent 5).

\section{Firm 3:}

The firm encourages teamwork as a means of individuals combining their knowledge to better understand and achieve organisational objectives.

"Good brains put together helps us in team work and organizing workshops and seminars in making co-workers understand the goal in pursuit" (Respondent 9).

\section{Firm 4:}

Responses gathered revealed that group-tacit knowledge is part of firm's resource to achieving its objectives. Most often seminars, conferences, trainings, workshops and board meetings are observed as means of sharing and combining knowledge among employees. During such trainings and meetings, employees discuss customer problems as well as other organisational objectives and brainstorm on possible solutions.

The firm also organizes employees into teams/groups with each team having unique projects that are geared towards the organisation's objectives. Then the firm maintains a knowledge base that stores experiences of employees.

"Employees are encouraged to share their ideas about how to achieve the organisation's goals each year" (Respondent 17).

"Ideas are gathered through conferences and responsibilities are assigned to departmental heads to carry-out" (Respondent 11).

"We create a knowledge base where experiences on the job is stored by members of staff" (Respondent 1).

\section{Theoretical and managerial contribution}

The Objective of this research was to explore the extent to which group-tacit knowledge positively influence organisational effectiveness. Based on the statistical analysis carried out, correlation and regression results showed that group-tacit knowledge strongly and significantly influences organisational effectiveness. Departing from existing literature's measurement of organisational effectiveness from an IT-based knowledge perspective, this research work is novel in its adoption of organisational knowledge resident in humans, especially tacit knowledge at the group level of organisations, to determine organisational effectiveness. The analysis of this hypothesis was carried out by, firstly, testing the relationships between group-tacit knowledge and organisational effectiveness based on responses gathered from employees of the telecommunication organisations.
Secondly, an inter-item correlation test was carried out to determine specific areas of relationship between group-tacit knowledge and organisational effectiveness items. Thirdly, ANOVA analysis was used to identify any possible differences among perception of employees of the four organisations about the hypothesized relationship.

The first stage of the analysis used correlation and regression statistics to examine the relationship between grouptacit knowledge and organisational effectiveness in the four telecommunication organisations. The result from correlation and regression tables indicate that employees of the four firms generally have a strong perception of group-tacit knowledge use to achieve the organisational effectiveness. The results discovered here is in alignment with the strong mean scores and the evidence of clustering around the mean as indicated by standard deviations attached to group-tacit knowledge and organisational effectiveness.

The results from correlation statistics, showed that all items of group-tacit knowledge has significant levels of relationship with the items of organizational effectiveness used in this study. The use of organisational culture bound knowledge of the organisation, relates with the adaptability of the organization to unanticipated changes, its responsiveness to newer market demands, coordinated and collective patterns among units in the organizations to achieve corporate goals and top management's ability to adapt the firm's goals and objectives to industry changes. Essentially, this means that the firm has a strong and competitive culture which its industry competitors cannot easily detect and copy. This culture resides in the behaviour and responsiveness of its employees such that they are able, to some extent, to define the pace of competitive complexity that exist in the industry (Agbim et al. 2013, Adeniji et al. 2014). Dynamism in competition might also not be a major challenge to the firm's management because they could have rich knowledge about the industry to the extent that they can forecast and predict trends (Li et al. 2010, Uchebulam et al. 2015). In all of these, there is a show of expertise and years of experience at the top management level where strategies are made to design/redesign goals that respond to demands and changes in the competitive industry and thus achieve organisational effectiveness.

This could imply that at smaller units of a large firm, the ability of group and team members to share knowledge and experiences towards achieving group goals and objectives accounts for most of the overall organisational effectiveness (Awodoyin et al. 2016). Employees of the organisations, most likely, have a sense of identity with the firm and therefore get bound by the organisation's corporate culture. A sense of purpose and recognition might be instilled into them. It is also important that team/group leaders encourage story-telling and mentorship among group members (Oganisjana et al. 2017). This can be an essential way of 
getting difficult job tasks resolved within shorter time and with less efforts (Swap et al. 2001, Ibidunni et al. 2017). Having smaller units of the large firm can be an essential means of stimulating knowledge sharing practices among group members. This can be made possible, when these smaller units are guided by leaders or supervisors who have experience about the job tasks given to the group, if they are willing to share their experience for the benefit of members of the group, and are willing to instil a sense of diplomacy and diplomatic leadership in the group.

Generally, the positive interrelationship among all items of group-tacit knowledge and organisational effectiveness indicate that organizational managers can influence positive organizational success in all areas of organizational objectives. This can be achieved by ensuring that group-tacit knowledge sharing becomes a part of the organizational culture that guide the way job is done, storytelling about past successes and failures in the organization is encourages among employees as a part of their learning activity, and group brainstorming is increasingly permitted in the organization (Nonaka et al. 2000, Giedraitis et al. 2017). They can also enhance organizational effectiveness through sharing of experiences and mentoring as a strategic path to ensuring tacit knowledge transfer among organizational members.

\section{Conclusion and recommendation}

The major focus of this study was to examine the effect of group-tacit knowledge on organisational effectiveness using Nigeria's telecommunication industry as a study area. Based on a survey of 230 managers and other administrative \& technical employees of the four major firm in the Global System for Mobile Communication (GSM) sub-market, it is concluded that group-tacit knowledge significantly influences organisational effectiveness. The study made new insights to existing strategic and knowledge management research, by revealing that the use of organisational culture bound knowledge, ideas of employees that are shared during conferences, team leaders' mentoring role, and collective reasoning over task relates with the adaptability of the organization to unanticipated changes, its responsiveness to newer market demands, and top management's ability to adapt the firm's goals and objectives to industry changes. Consequently, the recommendation from this research is that managers should create systems in the organisation that makes group-tacit knowledge sharing and interaction possible among employees. The manifestation of group knowledge in organisations should be both in information technology and direct human to human relationships, such that organisational objectives can be easily achieved.

\section{Acknowledgements}

Authors of this research work express sincere appreciation to the Management of Covenant University for giving full sponsorship to the publication of the research work in this publication.

\section{References}

Adeniji A, Osibanjo AO, Abiodun AJ, Oni-Ojo EE (2014) Corporate image: a strategy for enhancing customer loyalty and profitability. Proceedings of the 23rd International Business Information Management Association Conference, 1, 16871695.

Agag G, El-Masry AA (2016) Understanding consumer intention to participate in online travel community and effects on consumer intention to purchase travel online and WOM: an integration of innovation diffusion theory and TAM with trust. Computers in Human Behavior 60: 97-111. https://doi. org/10.1016/j.chb.2016.02.038

Agbim KC, Owutuamor ZB, Oriarewo GO (2013) Entrepreneurship development and tacit knowledge: exploring the link between entrepreneurial learning and individual know-how. Journal of Business Studies Quarterly 5 (2): 111-129.

Alabar TT, Egena O, Gbande RI (2014) Service quality and customer satisfaction in Nigerian mobile telephony. 3rd International Conference on Business, Management and Governance, IPEDR 82, Singapore.

Alsharoa M, Greggb D, Ramirez R (2017) Virtual team effectiveness: the role of knowledge sharing and trust. Information \& Management 54: 479-490. https://doi.org/10.1016/j. im.2016.10.005

Awodoyin A, Osisanwo T, Adetoro N, Adeyemo I (2016) Knowledge sharing behaviour pattern analysis of academic librarians in Nigeria. Journal of Balkan Libraries Union 4 (1): 12-19.

Brown JD (2000) What is construct validity? Shiken: JALT Testing \& Evaluation SIG Newsletter 4 (2): 8-12.

Chilton MA, Bloodgood JA (2007) The dimensions of tacit \& explicit knowledge: a description and measure. Proceedings of the 40th Hawaii International Conference on System Sciences. https://doi.org/10.1109/HICSS.2007.524

Consumer Protection Council (CPC) (2010) The Nigerian consumer voice, April-June.

Cunningham JB (1977) Approaches to the evaluation of organizational effectiveness. Academy of Management Review 2: 463-474.

Daft RL (1995) Organization theory and design. $5^{\text {th }}$ edition. Minneapolis/St. Paul: West Educational Publishing.

Dobrovolskienė N, Tvaronavičienė $M$, Tamošiūnienẻ R (2017) Tackling projects on sustainability: a Lithuanian case study. Entrepreneurship and Sustainability Issues 4 (4): 477-488. https://doi.org/10.9770/jesi.2017.4.4(6)

Erden Z, Von Krogh G, Kim S (2012) Knowledge sharing in an online community of volunteers: the role of community munificence. European Management Review 9 (4): 213-227. https://doi.org/10.1111/j.1740-4762.2012.01039.x 
Fei J, Chen S, Chen SL (2009) Organisational knowledge base and knowledge transfer in the shipping industry. Electronic Journal of Knowledge Management 7 (3): 325-340.

Giedraitis A, Stašys R, Skirpstaite R (2017) Management team development opportunities: a case of Lithuanian furniture company. Entrepreneurship and Sustainability Issues 5 (2): 212-222. https://doi.org/10.9770/jesi.2017.5.2(4)

Giti A, Suhaida bAK (2012) A review on the models of organisational effectiveness: a look at Cameron's model in higher education. International Education Studies 5(2): 80-87.

Goffin K, Koners U (2011) Tacit knowledge, lessons learnt, and new product development. The Journal of Product Innovation Management 28 (2): 300-318. https://doi.org/10.1111/j.15405885.2010.00798.x

Gold AH, Malhotra A, Segars AH (2001) Knowledge management: an organisational capabilities perspective. Journal of Management Information Systems 18 (1): 185-214. https:// doi.org/10.1080/07421222.2001.11045669

Hinton B (2003) Knowledge management and communities of practice: an experience from Rabobank Australia and New Zealand. International Food and Agribusiness Management Review 5 (3) http://ageconsearch.umn.edu/ bitstream/34328/1/0503hi01.pdf

Hostle JS, Fields D (2010) Trust and tacit knowledge sharing and use. Journal of Knowledge Management 14 (1): 128-140. https://doi.org/10.1108/13673271011015615

Hsin-Kuang C, Chun-Hsiung L, Dorjgotov B (2012) The moderating effect of transformational leadership on knowledge management and organisational effectiveness. Social Behavior and Personality 40 (6): 1015-1024. https://doi.org/10.2224/ sbp.2012.40.6.1015

Huang Y (2014) Measuring individual and organisational knowledge activities in academic libraries with multilevel analysis. The Journal of Academic Librarianship 40 (5): 436-446. https://doi.org/10.1016/j.acalib.2014.06.010

Ibidunni AS, Ogunnaike OO, Abiodun AJ (2017) Extending the knowledge strategy concept: linking organizational knowledge with strategic orientations. Academy of Strategic Management Journal 16 (3): 1-11.

Jad SMM, Geravandi S, Mohammadi MJ, Alizadeh R, Sarvarian M, Rastegarimehr B, Afkar A, Yari AR, Momtazan M, Valipour A, Mahboubi M, Karimyan A, Mazraehkar A, Nejad AS, Mohammadi H (2017) The relationship between knowledge of leadership and knowledge management practices in the food industry in Kurdistan province, Iran. Data in Brief 15: 155-159. https://doi.org/10.1016/j.dib.2017.09.031

Jankalová M, Jankal R (2017) The assessment of corporate social responsibility: approaches analysis. Entrepreneurship and Sustainability Issues 4 (4): 441-459. https://doi.org/10.9770/ jesi.2017.4.4(4)

Jasimuddina SM, Naqshbandib MM (2018) Knowledge-oriented leadership and open innovation: role of knowledge management capability in France-based multinationals. International Business Review (in Press). https://doi.org/10.1016/j. ibusrev.2017.12.001

Johnson RB, Onwuegbuzie AJ (2004) Mixed methods research: a research paradigm whose time has come. Educational Researcher 33 (7): 14-26. https://doi.org/10.3102/0013189X033007014
Kothari A, Rudman D, Dobbins M, Rouse M, Sibbald S, Edwards N (2012) The use of tacit and explicit knowledge in public health: a qualitative study. Implementation Science 7 (20): 1-12. https://doi.org/10.1186/1748-5908-7-20

Kovacic I, Filzmoser M, Denk F (2014) Interdisciplinary design: influence of team structure on project success. Procedia Social and Behavioral Sciences 119: 549-556. https://doi. org/10.1016/j.sbspro.2014.03.061

Kroeger A, Weber C (2015) Developing a conceptual framework for comparing social value creation. Academy Of Management Review 4015 (1): 43-70.

Li Y, Chang K-C, Chen H-G, Jiang JJ (2010) Software development team flexibility antecedents. Journal of System Software 83 (10): 1726-1734. https://doi.org/10.1016/j.jss.2010.04.077

Mahroeian H, Forozia A (2012) Challenges in managing tacit knowledge: a study on difficulties in diffusion of tacit knowledge in organisations. International Journal of Business and Social Science 3 (19): 303-308.

Matthews JR (2011) Assessing organisational effectiveness: the role of performance measures. The Library Quarterly: Information, Community, Policy 81 (1): 83-110.

Molina-Azorin JF (2012) Mixed methods research in strategic management: impact and applications. Organisational Research Methods 15 (1): 33-56. https://doi. org/10.1177/1094428110393023

Naser V, Sajad R (2017) Does Web 2.0 utilisation lead to knowledge quality, improvisational creativity, compositional creativity, and innovation in small and medium-sized enterprises? A sense-making perspective. Technology Analysis \& Strategic Management 29 (4): 381-394. https://doi.org/10.1080/09537 325.2016 .1213806

Nasimi MH, Nasimi S, Kasmaei MS, Kasmaei HS, Basirian F, Musapour H (2013) Knowledge and competitive advantage for organisations. Kuwait Chapter of Arabiam Journal of Business and Management Review 2 (5): 56-64. https://doi. org/10.12816/0001188

Nemani RR (2009) Research methodologies used in knowledge management: a literature review. MWAIS 2009 Proceedings. Paper 13. http://aisel.aisnet.org/mwais2009/13

Nonaka I, Toyama R, Konno N (2000) SECI, ba and leadership: a unified model of dynamic knowledge creation. Long Range Planning 33: 4-34. https://doi.org/10.1016/S00246301(99)00115-6

Obeidat BY, Tarhini A, Masa'deh R, Aqqad NO (2017) The impact of intellectual capital on innovation via the mediating role of knowledge management: a structural equation modelling approach. International Journal of Knowledge Management Studies 8 (3-4): 273-298. https://doi.org/10.1504/ IJKMS.2017.087071

Oganisjana K, Svirina A, Surikova S, Grīnberga-Zālīte G, Kozlovskis $\mathrm{K}$ (2017) Engaging universities in social innovation research for understanding sustainability issues. Entrepreneurship and Sustainability Issues 5 (1): 9-22. https://doi. org/10.9770/jesi.2017.5.1(1)

Ogbari ME, Ibidunni AS, Ogunnaike OO, Olokundun MA, Amaihian AB (2018) Comparative analysis of small business strategic orientation: implications for performance. Academy of Strategic Management Journal 17 (1): 1 1939-6104-17-1-164. 
Oghojafor ABE, Ladipo PKA, Ighomerebo SO, Odunewu VA (2014) Determinants of customer satisfaction and loyalty in the Nigerian telecommunications industry. British Journal of Marketing Studies 2 (5): 67-83.

Ojeka S, Iyoha F, Ibidunni A, Ayo C, Gberevbie D (2016) Role of e-Government in Nigeria's tax system: strategy perspective to enhance compliance. $16^{\text {th }}$ European Conference on e-Government, July 16-17, Ljubljana, Slovania.

Olaisen J, Revang O (2017) The dynamics of intellectual property rights for trust, knowledge sharing and innovation in project teams. International Journal of Information Management 37: 583-589. https://doi.org/10.1016/j.ijinfomgt.2017.05.012

Orlikowski WJ (2002) Knowing in practice: enacting a collective capability in distributed organizing. Organisation Science 13 (3): 249-273. https://doi.org/10.1287/orsc.13.3.249.2776

Osabuohien ES, Efobi UR (2012) Technology diffusion and economic progress in Africa: challenges and opportunities. Disruptive Technologies, Innovation and Global Redesign: Emerging Implications, 425-440. https://doi.org/10.4018/9781-4666-0134-5.ch024

Pae HK (2012) Construct validity of the Pearson test of English academic: a multitrait-multimethod approach. Pearson language test http://pearsonpte.com/wp-content/ uploads/2014/07/ResearchNoteConstructvalidityfinal201210-02gj.pdf

Pallant J (2005) SPSS Survival Manual, a step by step guide to data analysis using SPSS for Windows (Version 12). Allen \& Unwin, Australia.

Pivar J, Malbašić I, Horvat J (2012) Literature analysis of transfer and learning tacit knowledge. Central European Conference on Information and Intelligence Systems, held September 19-21, Varaždin, Croatia, 138-493.

Plano Clark VL (2010) The adoption and practice of mixed methods: U.S. trends in federally funded health-related research. Qualitative Inquiry 16 (6): 428-440. https://doi. org/10.1177/1077800410364609

Rehman WU, Asghar N, Ahmad K (2015) Impact of KM practices on firms' performance: a mediating role of business process capability and organizational learning. Pakistan Economic and Social Review 53 (1): 47-80.

Selden SC, Sowa JE (2015) Voluntary turnover in nonprofit human service organizations: the impact of high performance work practices. Human Service Organizations: Management, Leadership \& Governance 39 (3): 182-207. https://doi.org/10. $1080 / 23303131.2015 .1031416$

Shiaw-Tong H, May-Chiun LB, Yin-Chai W (2016) Relationship between knowledge management and organizational performance: a test on SMEs in Malaysia. Procedia - Social and Behavioral Sciences 224: 184-189. https://doi.org/10.1016/j. sbspro.2016.05.438
Stjepanović S, Tomić D, Škare M (2017) A new approach to measuring green GDP: a cross-country analysis. Entrepreneurship and Sustainability Issues 4 (4): 574-590. https://doi. org/10.9770/jesi.2017.4.4(13)

Swap W, Leonard D, Shields M, Abrams L (2001) Using mentoring and storytelling to transfer knowledge in the workplace. Journal of Management Information Systems 18 (1): 95-114. https://doi.org/10.1080/07421222.2001.11045668

Swart J, Pye A (2003) Collective tacit knowledge: integrating categories in the process of organisational learning. Organisational Learning and Knowledge International Conference, Lancaster University.

Taylor B, Sinha G, Goshal T (2014) Research methodology: a guide for researchers in management and social sciences, New Delhi: India PHI Learning Private Limited.

Uchebulam P, Akinyele S, Ibidunni A (2015) Competitive strategies and performance of selected SMEs in Nigeria. Proceedings of the International Conference on African Development Issues 2015, Covenant University, Ota, Nigeria.

Urbancová H (2013) Competitive advantage achievement through innovation and knowledge. Journal of Competitiveness 5 (1): 82-96. https://doi.org/10.7441/joc.2013.01.06

Weiner B (2007) Examining emotional diversity in the classroom: an attribution theorist considers the moral emotions. In: Schutz PA, Pekrun R (Eds) Emotion in education. San Diego, Ca: Academic Press, 75-88. https://doi.org/10.1016/ B978-012372545-5/50006-X

Yang J-T (2015) Effect of internal marketing on knowledge sharing and organisational effectiveness in the hotel industry. Total Quality Management and Business Excellence 26 (1): 76-92. https://doi.org/10.1080/14783363.2012.661131

Zavadskas EK, Govindan K, Antucheviciene J, Turskis Z (2016) Hybrid multiple criteria decision-making methods: a review of applications for sustainability issues. Economic ResearchEkonomska Istraživanja 29 (1): 857-887. https://doi.org/10.1 080/1331677X.2016.1237302

Zhang L, He J, Zhou S (2013) Sharing tacit knowledge for integrated project team flexibility: case study of integrated project delivery. Journal of Construction Engineering and Management 139 (7): 795-804. https://doi.org/10.1061/(ASCE) CO.1943-7862.0000645

Zheng W, Yang B, McLean GN (2010) Linking organisational culture, structure, strategy, and organisational effectiveness: mediating role of knowledge management. Journal of $\mathrm{Bu}-$ siness Research 63 (7): 763-771. https://doi.org/10.1016/j. jbusres.2009.06.005

Zoogah DB, Peng MW, Woldu H (2015). Institutions, resources, and organisational effectiveness in Africa. The Academy Of Management Perspectives 29 (1): 7-31. https://doi. org/10.5465/amp.2012.0033 